Jurnal Akuntansi dan Keuangan

Vol. 10 No. 2 Oktober 2021
FEB Universitas Budi Luhur

p-ISSN: 2252-7141

e-ISSN: 2622-5875

\title{
PENGARUH STRUKTUR ASET, PROFITABILITAS, LIKUIDITAS DAN RISIKO BISNIS TERHADAP STRUKTUR MODAL PADA PERUSAHAAN SEKTOR INDUSTRI BARANG KONSUMSI
}

\author{
Desy Mariani ${ }^{1}$ \\ Suryani ${ }^{2}$ \\ Program Studi Akuntansi, Fakultas Ekonomi dan Bisnis, Universitas Budi Luhur ${ }^{1,2}$ \\ Email: desy.mariani@budiluhur.ac.id ${ }^{1}$, suryani@budiluhur.ac.id ${ }^{2}$
}

\begin{abstract}
This study aims to examine the effect of Asset Structure, Profitability, Liquidity and Business Risk on Capital Structure in Manufacturing Companies in the Consumer Goods Industry Sector listed on the Indonesia Stock Exchange for the 2016-2020 period. The method used in this study is a quantitative method. The data used is secondary data obtained from financial reports published on www.idx.co.id. The population of this research is all manufacturing companies in the consumer goods industry sector listed on the Indonesia Stock Exchange for the 2016-2020 period totaling 64 companies. The sampling technique in this study used purposive sampling method with a total sample of 38 companies. This study uses descriptive statistical analysis and multiple linear regression. The results showed that Liquidity had a negative and significant effect on Capital Structure, while Asset Structure, Profitability and Business Risk had no effect on Capital Structure.
\end{abstract}

Keywords: asset structure, profitability, liquidity, business risk and capital structure.

\begin{abstract}
ABSTRAKSI
Penelitian ini bertujuan untuk menguji pengaruh Struktur Aset, Profitabilitas, Likuiditas dan Risiko Bisnis Terhadap Struktur Modal pada perusahaan Manufaktur Sektor Industri Barang Konsumsi yang terdaftar di Bursa Efek Indonesia periode 2016-2020. Metode yang digunakan dalam penelitian ini adalah metode kuantitatif. Data yang digunakan adalah data sekunder yang didapat dari laporan keuangan yang dipublikasikan di www.idx.co.id. Populasi penelitian ini adalah seluruh perusahaan Manufaktur sektor industri barang konsumsi yang terdaftar pada Bursa Efek Indonesia periode 2016-2020 berjumlah 64 perusahaan. Teknik penentuan sampel dalam penelitian ini menggunakan metode purposive sampling dengan jumlah sampel sebanyak 38 perusahaan. Penelitian ini menggunakan analisis statistik deskriptif dan regresi linier berganda- Hasil penelitian menunjukkan bahwa Likuiditas berpengaruh negatif dan signifikan terhadap Struktur Modal, sedangkan Struktur Aset, Profitabilitas dan Risiko Bisnis tidak berpengaruh terhadap Struktur Modal.
\end{abstract}

Kata Kunci: struktur aset, profitabilitas, likuiditas, risiko bisnis dan struktur modal 


\section{PENDAHULUAN}

Struktur modal perusahaan akan berubah seiring berjalannya suatu perusahaan. Perubahan struktur modal ini terjadi karena adanya faktor-faktor yang mempengaruhi struktur modal. Tetapi tidak selamanya perusahaan besar mampu mengandalkan modal dari dalam bila berhadapan dengan kebutuhan dana yang semakin tinggi akibat pertumbuhan perusahaan dan dana dari sumber internal semakin menipis, maka pilihan lain yang ditempuh adalah menggunakan dana yang berasal dari hutang (debt financing) maupun mengeluarkan saham baru (external equity financing) dalam memenuhi kebutuhan dananya. Pemenuhan dana diperoleh dari berbagal sumber dana seperti sumber pendanaan internal dan sumber pendanaan eksternal (Sudana, 2015). Dana yang diperoleh berasal dari pemilik perusahaan, cadangan, dan laba yang tidak dibagi merupakan modal sendiri atau berasal dari dana internal perusahaan, sedangkan dana yang diperoleh dari luar perusahaan seperti dari kreditur merupakan hutang atau pinjaman baik jangka panjang maupun jangka pendek bagi perusahaan. Manajer keuangan diharapkan agar dapat menerapkan dalam memilih sumber dana paling tepat (Widayanti et al., 2016).

Menurut Maswani et al. (2021) bahwa perusahaan tidak akan termotivasi untuk tumbuh jika hanya menggunakan dana internal dan juga tidak mengakses kebutuhan hutang untuk investasi masa depan. Hal ini dikarenakan perusahaan akan menggunakan hutang ketika benar-benar mengalami kesulitan keuangan, menghadapi risiko bisnis yang tinggi, atau ketika tidak dapat menyelesaikan pembayaran karena kekurangan uang tunai. Pada perusahaan di Indonesia keputusan pendanaan cenderung lebih banyak memanfaatkan modal dari dalam perusahaan sendiri sebagai modal pendanaan untuk membiayai operasionalnya dari pada modal asing. Modal asing dari investor dapat berupa pemilikan saham dan dapat juga berupa pinjaman kepada perusahaan, dimana perusahaan akan mencari pinjaman dana dari luar karena perusahaan sedang kekurangan dana. Dengan adanya pinjaman dana tersebut maka perusahaan harus mengalokasikan dana tersebut dengan tepat supaya perusahaan bisa bangkit dan mampu untuk melunasi utangnya tersebut. Investor yang mau menanamkan modalnya ke perusahaan harus mengalokasikan dana tersebut sebaik mungkin supaya investor tersebut yakin akan perusahaan dan tetap mau menanamkan modalnya. Besar kecilnya jumlah modal yang dimiliki perusahaan tidak dapat menjamin maju atau tidaknya suatu usaha. Maju atau tidaknya suatu usaha tergantung dari cara mengalokasikan modal yang ada dengan efektif dan efisien. 
Struktur modal yang baik akan berdampak pada keuangan perusahaan yang baik pula. Kesalahan dalam pengolahan struktur modal mengakibatkan utang yang besar, hal ini dapat menimbulkan risiko keuangan karena perusahaan tidak sanggup membayar beban bunga dan utang-utang maka nilai perusahaan akan menurun (Dewi \& Sudiartha, 2017). Hasil penelitian dari Listyawati et al. (2017) menyatakan bahwa struktur modal salah satu masalah yang penting bagi setiap perusahaan, karena tingkat struktur modal perusahaan akan mencerminkan status keuangan perusahaan, dimana keputusan manajer dapat meminimalkan modal perusahaan atau memaksimalkan nilai perusahaan. Kenaikan nilai perusahaan membuat investor tertarik untuk menanamkan modalnya di perusahaan sehingga dapat menimbulkan persaingan yang semakin ketat antar perusahaan. Meningkatnya nilai perusahaan membuat para investor tertarik untuk menanamkan modalnya dalam bentuk investasi pada perusahaan, hal tersebut dapat menimbulkan persaingan yang ketat antar perusahaan.

Struktur modal yang diukur dengan tingkat Debt to Equity Ratio (DER) yang merupakan perbandingan total hutang yang dimiliki perusahaan dengan modal sendiri. Semakin besar DER maka semakin besar pula resiko yang harus dihadapi perusahaan, karena pemakaian hutang sebagai sumber pendanaan jauh lebih besar dari pada modal sendiri (Fahmi, 2014). Ada banyak hal yang mempengaruhi struktur modal, seperti struktur aset, profitabilitas, likuiditas, dan risiko bisnis.

Struktur aktiva merupakan rasio atau keseimbangan antara aktiva lancar dan aktiva tetap yang akan menentukan struktur kekayaan (struktur aktiva). Struktur aktiva menunjukkan jumlah aktiva yang dapat digunakan sebagai jaminan kepada kreditor. Menurut teori balancing theories, apabila perusahaan memiliki aset sebagai hutang hipotek cenderung menggunakan utang dalam jumlah yang lebih besar, dengan meningkatnya aset tetap yang dimiliki, maka penggunaan utang juga akan meningkat. Artinya semakin besar aset tetap yang dimiliki oleh perusahaan, maka semakin besar pula aset tetap yang dapat dijadikan jaminan oleh perusahaan (Jati, 2016). Berdasarkan penelitian yang dilakukan oleh Suherman et al. (2019) menunjukkan bahwa struktur aset memiliki pengaruh positif signifikan terhadap struktur modal. Sedangkan pada penelitian lain yang dilakukan oleh Velda et al. (2020) menunjukkan bahwa struktur aset tidak bepengaruh terhadap struktur modal.

Profitabilitas digunakan untuk menilai kemampuan perusahaan untuk mencari keuntungan atau laba dalam satu periode tertentu. Pengukuran rasio Profitabilitas dapat 
dilakukan dengan membandingkan antara berbagai komponen yang ada didalam laporan laba rugi atau neraca. Pengukuran dapat dilakukan untuk beberapa periode. Tujuannya adalah untuk memonitor dan mengevaluasi tingkat perkembangan profitabilitas perusahaan dari waktu ke waktu. Jika perusahaan mampu memberikan prospek yang tinggi dan mendorong para investor untuk meningkatkan harga saham dengan cara menanamkan modalnya diperusahaan tersebut maka secara langsung mem pengaruhi nilai perusahaan karena harga saham yang semakin naik (Kasmir, 2016). Rasio yang digunakan untuk mengukur apakah terdapat struktur modal dalam penelitian ini adalah Return On Assets. Ketika nilai return on assets semakin kecil maka kinerja yang dilakukan perusahaan kurang efektif dalam mengelola aset yang dimliki untuk menghasilkan laba sehingga dapat menimbulkan kerugian yang berakibat pada arus kas negatif dan mengindikasikan perusahaan akan mengalami kondisi struktur modal (Muflihah, 2017). Berdasarkan penelitian yang dilakukan oleh Velda et al. (2020) dan Melisa \& Yuliandi (2020) menunjukkan bahwa profitabilitas memiliki pengaruh positif signifikan terhadap struktur modal. Sedangkan pada penelitian lain yang dilakukan oleh Suherman et al. (2019) dan Andika \& Sedana (2019) menunjukkan bahwa profitabilitas tidak berpengaruh terhadap struktur modal.

Rasio Likuiditas digunakan untuk menunjukkan atau mengukur kemampuan perusahaan dalam memenuhi atau melunasi kewajiban jangka pendek (hutang lancar) yang sudah jatuh tempo. Likuiditas yang tinggi akan menimbulkan banyak dana untuk membayar deviden, membiayai operasi perusahaan, serta melakukan investasi. Hal ini akan menimbulkan persepsi investor terhadap kinerja perusahaan. Jika kinerja perusahaan yang ditunjukkan baik, maka dapat dijadikan sinyal positif bagi para investor yang dapat berdampak bagi nilai perusahaan. Semakin besar likuiditas maka perusahaan semakin mampu melunasi kewajibannya sehingga perputaran kas didalam perusahaan sangat baik dan dapat memberikan persepsi positif terhadap kondisi perusahaan. Likuiditas yang tinggi menunjukkan kekuatan perusahaan dari segi kemampuan untuk memenuhi hutang lancar dari harta lancar yang dimiliki sehingga hal ini meningkatkan kepercayaan pihak luar terhadap perusahaan tersebut. Rasio likuiditas yang digunakan dalam memprediksi struktur modal adalah Current Ratio. Current ratio digunakan untuk mengukur kemampuan perusahaan untuk memenuhi kewajiban jangka pendeknya dengan menggunakan aktiva lancar. Berdasarkan penelitian yang dilakukan oleh Suherman et al. (2019) menunjukkan bahwa likuiditas memiliki pengaruh positif signifikan terhadap struktur modal. Sedangkan 
pada penelitian lain yang dilakukan oleh Komariah \& Nurulrahmatiah (2020) menunjukkan bahwa likuiditas tidak berpengaruh terhadap struktur modal.

Risiko Bisnis merupakan salah satu risiko yang dihadapi oleh perusahaan ketika menjalankan kegiatan operasinya, yaitu kemungkinan ketidakmampuan perusahaan untuk membiayai kegiatan operasionalnya. Semakin besar risiko bisnis perusahaan, makin rendah rasio utangnya yang optimal. Risiko bisnis dapat meningkat ketika perusahaan menggunakan hutang yang tinggi untuk memenuhi kebutuhan pendanaannya. Risiko akan timbul seiring dengan munculnya beban biaya atas pinjaman yang dilakukan perusahaan. Semakin besar beban biaya yang harus ditanggung maka risiko yang di hadapi perusahaan juga semakin besar. Sesuai dengan trade-off theorymenyatakan bahwa perusahaan dengan risiko bisnis yang tinggi akan meningkatkan pengunaan hutang sebagai sumber pendanaan perusahaan, sehingga semakin tinggi risiko bisnis dapat mengakibatkan meningkatnya struktur modal (Komariah \& Nurulrahmatiah, 2020). Berdasarkan penelitian yang dilakukan oleh Velda et al. (2020) menunjukkan bahwa risiko bisnis memiliki pengaruh negatif signifikan terhadap struktur modal.

Berdasarkan hasil penelitian terdahulu yang menunjukkan masih adanya research gap maka memunculkan perumusan masalah dalam penelitian berikut: "Bagaimana Pengaruh Struktur Aset, Profitabilitas, Likuiditas dan Risiko Bisnis Terhadap Struktur Modal Pada Perusahaan Manufaktur Sektor Industri Barang Kosumsi yang Terdaftar di Bursa Efek Indonesia Periode 2016-2020?". Tujuan penelitian ini adalah untuk mengetahui Pengaruh Struktur Aset, Profitabilitas, Likuiditas dan Risiko Bisnis Terhadap Struktur Modal Pada Perusahaan Manufaktur Sektor Industri Barang Kosumsi yang Terdaftar di Bursa Efek Indonesia Periode 2016-2020. Manfaat dari penelitian ini adalah Penelitian ini diharapkan mampu menjadi referensi bagi peneliti selanjutnya untuk mengembangkan ataupun membuat penelitian baru di bidang laporan keuangan khususnya di sektor industri barang konsumsi.

\section{TINJAUAN PUSTAKA DAN PENGEMBANGAN HIPOTESIS Teori Sinyal (Signaling theory)}

Teori sinyal adalah teori yang melandasi penggukapan sukarela dimana manajemen selalu ingin menunjukan berita baik kepada calon investor dan pemegang saham meskipun bersifat privasi (Muflihah, 2017). Teori Sinyal memberikan gambaran bahwa manajer melakukan pemberian sinyal berupa informasi pada laporan keuangan perusahaan. 
Informasi tersebut berfungsi sebagai usaha dalam mengurangi asimetri informasi. Muflihah (2017) menjelaskan teori sinyal dalam topik struktur modal menjelaskan jika kondisi keuangan baik dan keberadaannya masih stabil, manajer akan menyelenggarakan akuntansi liberal. Sebaliknya, jika kondisi keuangan buruk dan diragukan keberadaannya, manajer akan menyelenggarakan akuntansi konservatif. Sedangkan menurut Khairudin \& Wandita (2017) pengumuman informasi akuntansi memberikan sinyal bahwa perusahaan mempunyai prospek yang baik atau buruk di masa mendatang.

Apabila informasi keuangan memiliki penilaian yang baik maka informasi yang diterima investor merupakan good news sehingga investor tertarik untuk menginvestasikan dananya pada perusahaan seperti laba yang dilaporkan oleh perusahaan meningkat maka kinerja perusahaan tersebut baik karena bisa menghasilkan keuntungan yang berhubungan dengan pembagian deviden kepada pemegang saham. Sebaliknya bila informasi keuangan menunjukkan penilaian buruk maka informasi yang diterima investor adalah bad news dan investor akan memilih untuk menginvestasikan dananya diperusahaan lain. Penggunaan teori sinyal dinilai tepat dalam mempresentasikan sinyal positif (good news) dan sinyal negatif (bad news) pada variabel profitabilitas, likuiditas dan struktur modal, karena analisis rasio keuangan dapat menilai kondisi keuangan perusahaan.

\section{Struktur Modal}

Struktur modal adalah penggabungan dari sumber utang jangka panjang yang terdiri dari utang, saham biasa dan saham umum yang dipergunakan untuk memenuhi kegiatan perusahaannya. Dalam Manajemen keuangan perusahaan menjadi faktor terpenting dalam perusahaan karena untuk menentukan cara dalam memperoleh modal yang digunakan untuk membiayai investasi perusahaannya. Dengan demikian, manajemen keuangan harus dapat memastikan perusahaan didanai dengan biaya modal yang rendah dan investor yang menanamkan modalnya dengan jaminan hasil yang maksimal pada risiko paling kecil. Struktur modal dalam penelitian ini diukur dengan debt to equity ratio (DER) (Sartono, 2016).

$$
\text { Debt to equity rasio }(\text { DER })=\frac{\text { Total Hutang }(\text { Debt })}{\text { Ekuitas }(\text { Equity })}
$$

Sumber: Sartono (2016) 


\section{Struktur Aset}

Menurut Kasmir (2016) aktiva atau aset merupakan harta atau kekayaan yang dimiliki perusahaan, baik pada saat tertentu maupun periode tertentu. Struktur aset juga merupakan salah satu faktor yang dapat mempengaruhi kebijakan hutang. Struktur aset merupakan besarnya alokasidana untuk masing-masing komponen aset, baik aset lancar maupun aset tetap sedangkan aset tetap sering digunakan sebagai jaminan yang dapat meyakinkan pihak eksternal untuk memberikan pinjaman, sehingga perusahaan mempunyai aset tetap yang besar akan lebih mudah untuk memperoleh pinjaman. Proksi struktur aktiva diukur dengan membandingkan jumlah aktiva tetap dan total aktiva. Struktur aktiva menunjukkan jumlah aktiva yang dapat digunakan sebagai jaminan kepada kreditor.

\begin{tabular}{|c|c|}
\hline \multirow{2}{*}{ Struktur Aset = } & Aset Tetap \\
\hline & Total Aset \\
\hline
\end{tabular}

Sumber: Brigham dan Hauston (2011:175)

\section{Profitabilitas}

Menurut Fahmi (2017) menjelaskan bahwa rasio profitabilitas merupakan rasio yang mengukur efektivitas manajemen secara keseluruhan yang ditujukan oleh besar kecilnya tingkat keuntungan yang diperoleh dalam hubungannya penjualan maupun investasi. Rasio yang digunakan dalam penelitian ini Return on Assets (ROA). Rasio profitabilitas memberikan informasi terkait besarnya laba yang diperoleh dari penggunaan total asset ang dimiliki sebuah perusahaan. Penggunaan aset yang tidak efektif akan menyebabkan perusahaan sulit untuk mendapatkan atau meningkatkan laba.

Return on assets $(R O A)=\frac{\text { Laba Setelah Pajak }}{\text { Total Aset }}$

Sumber : Fahmi (2017)

\section{Likuiditas}

Menurut Fahmi (2017) menjelaskan bahwa rasio likuiditas merupakan kemampuan suatu perusahaan memenuhi jangka pendeknya secara tepat waktu. Sedangkan menurut (Khairuddin et al., 2019) menjelaskan bahwa rasio likuiditas adalah suatu indikator tentang kemampuan perusahaan yang membayar semua kewajiban finansial jangka pendek ketika sudah jatuh tempo dengan mempergunakan aktiva lancar yang masih tersedia atau dengan 
kata lain bisa menggambarkan kemampuan suatu perusahaan dalam memenuhi kewajiban atau utang jangka pendek. Likuiditas dalam penelitian ini diukur dengan menggunakan Current Ratio. Current Ratio merupakan rasio yang menunjukkan perbandingan antara aset lancar (Current assets) dengan hutang lancar (Current liabilitas) untuk mengetahui kemampuan perusahaan dalam membayar hutang lancar perusahaan (Sari \& Suryantini, 2019). Selain itu, current ratio menunjukkan besarnya hutang kewajiban lancar yang ditutup dengan aset yang kemudian diharpakan akan dikonversi menjadi kas dalam jangka pendek (Aset lancar).

Current Ratio $(C R)=\frac{\text { Current Assets }}{\text { Current Liabilities }}$

Sumber: Fahmi (2017)

\section{Risiko Bisnis}

Risiko merupakan risiko bisnis dari gabungan (aliansi) dengan keputusan bisnis dalam jangka panjang diciptakan oleh penyelenggara bisnis tersebut. Tinggi rendahnya risiko bisnis berkaitan dengan tingkat pengembalian, digambarkan dengan high return, high risk yaitu suatu perusahaan yang mempunyai tingkat penjualan yang cukup stabil dengan perusahaan yang tingkat penjualannya tinggi (Bong, 2019).

Risiko bisnis merupakan risiko yang berkaitan dengan pendapatan dan beban tetap. Risiko pendapatan dapat dihubungkan dengan ketidakpastian dari penjualan. Ketidak pastian merupakan keadaan yang dihadapi seseorang dimasa yang akan datang ada sejumlah kemungkinan yang akan terjadi tidak diketahui. Suatu keadaan yang dihadapi oleh seorang pemimpin perusahaan adalah risiko, artinya sejumlah kemungkinan hasil yang diketahui atau suatu peristiwa diantara peristiwa yang mungkin terjadi. Selain pendapatan, beban tetap berhubungan dengan struktur biaya perusahaan. Dalam penelitian ini risiko bisnis diukur dengan menggunakan risk. Risk merupakan rasio yang menunjukkan perbandingan antara EBIT dengan total aset.

$$
\text { Risk }=\frac{E B I T}{\text { Total Aset }}
$$

Sumber : (Gitman, 2012) 


\section{Pengembangan Hipotesis}

\section{Pengaruh Struktur Aset terhadap Struktur Modal}

Weston \& Copeland (2010) menyatakan bahwa Perusahaan yang mempunyai aktiva tetap jangka panjang lebih besar, maka perusahaan tersebut akan banyak menggunakan hutang jangka panjang, dengan harapan aktiva tersebut dapat digunakan untuk menutup tagihannya. Semakin besar struktur aktiva yang dimiliki perusahaan, maka semakin besar pula peluang perusahaan untuk menggunakan utang dalam jumlah yang besar sebagai jaminanan atas utang perusahaan karena apabila terjadi kebangkrutan, maka perusahaan dapat melunasi kewajibannya kepada investor. Hasil penelitian yang dilakukan oleh Aurelia \& Setijaningsih (2020) menunjukan bahwa struktur aset berpengaruh positif dan signifikan terhadap struktur modal. Maka dirumuskan hipotesis pertama yaitu:

$\mathrm{H}_{1}$ : Struktur Aset berpengaruh positif dan signifikan terhadap struktur modal.

\section{Pengaruh Profitabilitas Terhadap Struktur Modal}

Rasio return on assets merupakan rasio yang digunakan untuk mengukur efektivitas manajemen secara keseluruhan yang ditunjukan oleh besar kecilnya tingkat keuntungan yang diperoleh dalam hubungannya dengan penjualan maupun investasi. Perusahaan dalam keadaan baik apabila laba yang diperoleh perusahaan mengalami pertumbuhan, akan tetapi ketika perusahaan mengalami tekanan keuangan return on assets akan turun dari tahun sebelumnya dan mencapai angka negatif. Hal tersebut dibuktikan dengan menurunnya tingkat keuntungan akan berpengaruh terhadap keadaan keuangan perusahaan yang semakin menurun (Sutra \& Mais, 2019). Hasil penelitian yang dilakukan oleh Dewi \& Sudiartha (2017) menunjukan bahwa profitabilitas berpengaruh positif dan signifikan terhadap struktur modal. Maka dirumuskan hipotesis pertama yaitu:

$\mathrm{H}_{2}$ : Profitabilitas berpengaruh negatif dan signifikan terhadap struktur modal.

\section{Pengaruh Likuiditas Terhadap Struktur Modal}

Menurut Fahmi (2017) menjelaskan bahwa rasio likuiditas merupakan kemampuan suatu perusahaan memenuhi jangka pendeknya secara tepat waktu. Current ratio sangat penting karena memperlihatkan seberapa besar kesanggupan perusahaan melunasi hutang lancar ketika jatuh tempo atau ketika ditagih. Jika suatu perusahaan mengalami masalah dalam likuiditas maka sangat memungkinkan perusahaan tersebut mulai memasuki masa kesulitan keuangan, dan jika kondisi kesulitan kesulitan tersebut tidak cepat diatasi maka 
perusahaan bisa berakibat pada kondisi kebangkrutan (Fahmi, 2017). Hasil penelitian yang dilakukan oleh (Liang \& Natsir, 2019) menunjukan bahwa likuiditas berpengaruh negatif dan signifikan terhadap struktur modal. Maka dirumuskan hipotesis pertama yaitu:

$\mathrm{H}_{3}$ : likuiditas berpengaruh negatif dan signifikan terhadap struktur modal.

\section{Pengaruh Risiko Bisnis Terhadap Struktur Modal}

Risiko bisnis merupakan ketidakpastian yang dihadapi oleh perusahaan dalam menjalankan kegiatan operasinya Perusahaan memiliki risiko bisnis kecil jika permintaaan seperti produk, harga masukan dan produk stabil. Semakin rendah risiko bisnis perusahaan maka akan berakibat pada tingginya risiko utang yang optimal (Puspida \& Budiyanto, 2013). Jika risiko bisnis mengalami kenaikan maka struktur modal akan mengalami penurunan dan juga sebaliknya. Dimana bagi perusahaan yang memiliki tingkat yang tinggi dalam risiko bisnis, sangat tidak efisien bagi mereka untuk menggunakan utang yang tinggi. Karena jika dilihat dari histori risiko bisnis perusahaan yang tinggi, investor juga pastinya akan menolak untuk menanamkan modal yang tinggi di perusahaan itu dan juga bisa menghambat proses pelunasan utang. Hasil penelitian yang dilakukan oleh Wiagustini \& Pertamawati (2015) menunjukan bahwa risiko bisnis berpengaruh negatif dan signifikan terhadap struktur modal. Maka dirumuskan hipotesis pertama yaitu:

$\mathrm{H}_{4}$ : Risiko bisnis berpengaruh negatif dan signifikan terhadap struktur modal.

\section{METODE PENELITIAN}

Populasi yang digunakan adalah perusahaan yang terdaftar pada Bursa Efek Indonesia yaitu perusahaan sektor industri barang konsumsi periode 2016-2020 dengan jumlah perusahaan sebanyak 64 perusahaan. Dalam penelitian ini teknik pengambilan sampel yang digunakan yaitu purposive sampling. Dengan alasan tidak semua sampel memiliki kriteria yang sudah ditentukan. Kriteria sampel yang ditentukan adalah perusahaan manufaktur sektor industri barang konsumsi yang sudah terdaftar pada Bursa Efek Indonesia dengan menerbitkan laporan keuangan secara lengkap dalam mata uang rupiah periode 2016-2020. Jumlah perusahaan yang memenuhi kriteria tersebut hanya berjumlah 38 perusahaan sehingga jumlah data yang diobservasi dalam 5 tahun periode penelitian berjumlah 190 data. Data dalam penelitian ini dianalisis secara deskriptif dan Regresi Linier Berganda. 


\section{PEMBAHASAN}

\section{Statistik Deskriptif}

Statistik deskriptif dilakukan untuk memberikan gambaran mengenai jumlah data yang digunakan dalam penelitian menunjukkan nilai minimum, nilai maksimum, nilai ratarata, dan standar deviasi.

Tabel 1. Statistik Deskriptif

\begin{tabular}{lcrrrr}
\hline & $\mathrm{N}$ & \multicolumn{1}{c}{ Minimum } & \multicolumn{1}{c}{ Maximum } & \multicolumn{1}{c}{ Mean } & \multicolumn{1}{c}{ Std. Deviation } \\
\hline Struktur Aset & 149 & $-3,79$ &,- 46 & $-1,1886$ &, 56682 \\
Profitabilitas & 149 & $-10,95$ &,- 08 & $-2,7446$ & 1,55073 \\
Likuiditas & 149 & $-2,51$ & 4,42 &, 8207 &, 78765 \\
Risiko Bisnis & 149 & $-7,73$ & 1,18 & $-2,4604$ & 1,35177 \\
Struktur Modal & 149 & $-2,49$ & 1,60 &,- 5694 &, 78842 \\
Valid N (listwise) & 149 & & & & \\
\hline
\end{tabular}

Tabel 1 menunjukan hasil statistik deskriptif masing-masing variabel penelitia. Variabel struktur aset memiliki nilai minimum $-3,79$, nilai maksimum $-0,46$, nilai rata-rata $-1,1886$ dan standar deviasi 0,56682. Variabel profitabilitas memiliki nilai minimum -10,95, nilai maksimum $-0,08$, nilai rata-rata $-2,7446$ dan standar deviasi 1,55073 . Variabel likuiditas memiliki nilai minimum $-2,51$, nilai maksimum 4,42, nilai rata-rata 0,8207 dan standar deviasi 0,78765. Variabel risiko bisnis memiliki nilai minimum -7,73, nilai maksimum 1,18 , nilai rata-rata $-2,4604$ dan standar deviasi 1,35177. Variabel struktur modal memiliki nilai minimum -2,49, nilai maksimum 1,60, nilai rata-rata -0,5694 dan standar deviasi 0,78842.

\section{Uji Asumsi Klasik}

Uji asumsi klasik dilakukan dengan beberapa tahap dan beberapa macam uji. Pengujian asumsi klasik dalam penelitian ini terdiri dari uji normalitas, uji multikolinearitas, uji heteroskedastisitas dan uji autokorelasi. Ringkasan hasil uji asumsi klasik terdapat pada tabel 2 
Tabel 2. Uji Asumsi Klasik

\begin{tabular}{|c|c|c|c|c|c|}
\hline \multicolumn{2}{|c|}{ Uji Normalitas } & \multicolumn{2}{|c|}{ Uji Heteroskedastisitas } & \multirow{2}{*}{$\begin{array}{c}\text { Uji } \\
\text { Multikolinearitas }\end{array}$} & \multirow{2}{*}{$\begin{array}{c}\text { Uji } \\
\text { Autokorelasi }\end{array}$} \\
\hline Normal P-Plot & $\begin{array}{l}\text { One-Sample } \\
\text { Kolmogorov }\end{array}$ & Scatterplot & Uji Glejser & & \\
\hline $\begin{array}{l}\text { titik-titik data } \\
\text { mendekati } \\
\text { garis diagonal } \\
\text { dan mengikuti } \\
\text { arah garis } \\
\text { diagonal }\end{array}$ & $\begin{array}{c}\text { Nilai sig } \\
(0,102)> \\
0,05\end{array}$ & $\begin{array}{l}\text { titik-titik data } \\
\text { menyebar } \\
\text { secara acak, } \\
\text { tidak } \\
\text { membentuk } \\
\text { pola tertentu } \\
\text { dan tersebar } \\
\text { baik. }\end{array}$ & $\begin{array}{c}\text { semua } \\
\text { variabel } \\
\text { nilai Sig > } \\
0,05\end{array}$ & $\begin{array}{c}\text { bahwa semua } \\
\text { variabel nilai } \\
\text { tolerance }>0,1 \\
\text { dan nilai VIF }< \\
10\end{array}$ & $\begin{array}{c}\text { hasil output } \\
\text { dapat } \\
\text { diketahui } \\
\text { bahwa nilai } \\
\text { DW }=1,992\end{array}$ \\
\hline \multicolumn{2}{|c|}{ Data berdistribusi normal } & \multicolumn{2}{|c|}{$\begin{array}{c}\text { Tidak terjadi } \\
\text { Heteroskedastisitas }\end{array}$} & $\begin{array}{c}\text { Tidak terjadi } \\
\text { multikolinearitas }\end{array}$ & $\begin{array}{l}\text { Tidak terjadi } \\
\text { Autokorelasi }\end{array}$ \\
\hline
\end{tabular}

\section{Analisis Regresi Linear Berganda}

Uji analisis regresi linear berganda dalam penelitian ini meliputi koefisien determinasi, uji statistik $f$ dan uji t.

Tabel 3. Uji Koefisien Determinasi

\begin{tabular}{llccl}
\hline Model & $\mathrm{R}$ & $\mathrm{R}$ Square & $\begin{array}{c}\text { Adjusted R } \\
\text { Square }\end{array}$ & $\begin{array}{c}\text { Std. Error of the } \\
\text { Estimate }\end{array}$
\end{tabular}

\begin{tabular}{lrrrr}
\hline 1 &, $718^{\mathrm{a}}$ &, 515 &, 502 &, 55656 \\
\hline
\end{tabular}

a. Predictors: (Constant), Risiko Bisnis, Struktur Aset, Likuiditas, Profitabilitas

b. Dependent Variable: Struktur Modal

Berdasarkan tabel 3 di atas, dapat diketahui nilai Adjusted $R$ Square adalah 0,502 yang berarti $50,2 \%$ dari nilai struktur modal ditentukan oleh struktur aset, profitabilitas, likuiditas dan risiko bisnis. sedangkan sisanya sebesar 49,8\% (100\%-50,2\%) ditentukan oleh variabel-variabel lainnya.

Tabel 4. Uji F

\begin{tabular}{rlrrrrr}
\hline Model & & $\begin{array}{c}\text { Sum of } \\
\text { Squares }\end{array}$ & df & Mean Square & F & Sig. \\
\hline \multirow{2}{*}{1} & Regression & 47,394 & 4 & 11,848 & 38,251 &, $000^{\text {b }}$ \\
& Residual & 44,605 & 144 &, 310 & & \\
\hline & Total & 91,998 & 148 & & & \\
\hline
\end{tabular}

a. Dependent Variable: Struktur Modal

b. Predictors: (Constant), Risiko Bisnis, Struktur Aset, Likuiditas, Profitabilitas

Berdasarkan tabel 4 di atas dapat diketahui bahwa nilai Fhitung sebesar 30,823 untuk nilai Ftabel sebesar $(5 \%, 4,144)$ 2,43 dan nilai signifikan sebesar 0,000. Maka dapat 
disimpulkan bahwa nilai Fhitung $(38,251)>$ Ftabel $(2,43)$ dan nilai signifikan 0,000<0,05 yang berarti bahwa variabel Struktur Aset, Profitabilitas, Likuiditas, Risiko Bisnis dan Struktur Modal dapat dinyatakan layak.

Tabel 5. Uji t

\begin{tabular}{|c|c|c|c|c|c|c|}
\hline \multirow[t]{2}{*}{ Model } & & \multicolumn{2}{|c|}{$\begin{array}{l}\text { Unstandardized } \\
\text { Coefficients }\end{array}$} & \multirow{2}{*}{$\begin{array}{c}\text { Standardized } \\
\text { Coefficients } \\
\text { Beta }\end{array}$} & \multirow[t]{2}{*}{$\mathrm{t}$} & \multirow[t]{2}{*}{ Sig. } \\
\hline & & B & Std. Error & & & \\
\hline \multirow[b]{5}{*}{ Rano } & (Constant) &,- 223 & 144 & & $-1,544$ & 125 \\
\hline & Struktur Aset &,- 044 & ,088 &,- 032 &,- 505 & 614 \\
\hline & Profitabilitas &,- 044 & ,048 &,- 087 &,- 922 & ,358 \\
\hline & Likuiditas &,- 702 & ,064 &,- 701 & $-11,017$ & ,000 \\
\hline & $\begin{array}{l}\text { Risiko Bisnis } \\
\text { ndent Variable }\end{array}$ & -,023 & ,055 &,- 039 &,- 412 & 681 \\
\hline
\end{tabular}

Uji statistik t ditentukan dengan melihat pada tabel Coefficients pada kolom t dan Sig. berdasarkan hasil olah data, diketahui bahwa hasil pengujian statistik variabel struktur aset memiliki nilai t hitung sebesar $-0,505<1,977$ dengan tingkat signifikan sebesar 0,614 $>0,05$, maka $\mathrm{H}_{1}$ ditolak. Hal ini dapat disimpulkan bahwa variabel struktur aset secara parsial tidak berpengaruh terhadap struktur modal. Hasil pengujian statistik variabel profitabilitas memiliki nilai t hitung sebesar -0,922 <1,977 dengan tingkat signifikan sebesar 0,358 >0,05, maka $\mathrm{H}_{2}$ ditolak. Hal ini dapat disimpulkan bahwa variabel profitabilitas secara parsial tidak berpengaruh terhadap struktur modal. Hasil pengujian statistik variabel likuiditas memiliki nilai t hitung sebesar $-11,017<1,977$ dengan tingkat signifikan sebesar 0,000 $<0,05$, maka $\mathrm{H}_{3}$ diterima. Hal ini dapat disimpulkan bahwa variabel likuiditas secara parsial berpengaruh negatif dan signifikan terhadap struktur modal. Hasil pengujian statistik variabel risiko bisnis memiliki nilai t hitung sebesar $-0,412$ $<$ 1,977 dengan tingkat signifikan sebesar 0,681 > 0,05, maka $\mathrm{H}_{4}$ ditolak. Hal ini dapat disimpulkan bahwa variabel risiko bisnis secara parsial tidak berpengaruh terhadap struktur modal.

\section{INTERPRETASI HASIL PENELITIAN}

\section{Pengaruh Struktur Aset Terhadap Struktur Modal}

Hasil dari penelitian ini menunjukan bahwa struktur aset tidak berpengaruh terhadap struktur modal dapat diartikan bahwa dengan ukuran besar atau kecilnya dari struktur aset tidak memberikan pengaruh terhadap hutang. Hal ini dikarenakan jika aset tetap memiliki 
proporsi yang tinggi dibandingkan dengan aset lancar, maka dapat berdampak pada mengurangi penggunaan hutang. Berdasarkan hal tersebut dapat disimpulkan jika dana internal mampu memenuhi operasional perusahaan selain itu juga risiko yang dimiliki relatif rendah. Beberapa perusahaan industri yang modalnya tertanam pada aset tetap lebih cenderung melakukan pemenuhan modalnya dari modal sendiri dan hutang yang ada memiliki peran sebagai pelengkap, maka bila dihubungkan dengan adanya struktur financial konservatif horizontal yang menjelaskan jika suatu modal sendiri yang besar memungkinkan dapat menutup jumlah aset lain yang memiliki sifat permanen. Demikian pula dari sebagian besar aset yang dimiliki perusahaan.

Hasil penelitian ini sesuai dengan hasil penelitian yang dilakukan oleh Permatasari et al. (2019) yang menyatakan bahwa struktur aset berpengaruh signifikan terhadap struktur modal. Namun, hasil penelitian ini tidak sesuai dengan penelitian yang dilakukan oleh Velda et al. (2020) yang menyatakan bahwa struktur aset tidak berpengaruh terhadap struktur modal.

\section{Pengaruh Profitabilitas Terhadap Struktur Modal}

Hasil dari penelitian ini menunjukan bahwa profitabilitas tidak berpengaruh terhadap struktur modal. Artinya profitabilitas yang diliat dari $R O A$, bukan menjadi faktor utama yang mempengaruhi struktur modal. Salah satu penyebab profitabilitas tidak berpengaruh pada struktur modal dikarenakan dalam beberapa tahun terakhir perusahaan manufaktur pada sektor industri barang kosumsi sedang mengalami masa resesi di mana perusahaan menghadapi masalah penurunan pada hasil penjualannya pada laba kotor yang akan berdampak pula pada jumlah laba yang diperoleh semakin kecil. Oleh karena itu, kreditur dan investor cenderung berorientasi pada rencana bisnis jangka panjang dengan harapan kondisi perekonomian akan membaik. Implikasinya adalah mereka cenderung mengabaikan tingkat profitabilitas dalam jangka pendek, sehingga profitabilitas tidak berpengaruh pada struktur modal (Riasita, 2014).

Hal ini tidak sesuai dengan teori sinyal yang mengatakan ketika suatu perusahaan menghasilkan laba maka perusahaan akan meningkatkan pembayaran hutangnya yang berarti semakin besar keuntungan yang dperoleh maka semakin besar kemampuan perusahaan untuk membayar hutang (Trisna \& Gayatri, 2019). Hasil penelitian ini sesuai dengan penelitian yang dilakukan oleh Septiani \& Suaryana (2018) yang menyatakan bahwa profitabilitas tidak berpengaruh terhadap struktur modal. 


\section{Pengaruh Likuiditas Terhadap Struktur Modal}

Hasil dari penelitian ini menunjukan bahwa likuiditas berpengaruh negatif dan signifikan terhadap struktur modal. Perusahaan yang memiliki tingkat likuiditas yang tinggi akan mampu memberikan gambaran suatu perusahaan bahwa perusahaan tersebut mampu memenuhi kewajiban jangka pendeknya yang berarti akan memberikan pengaruh baik kepada investor sehingga investor akan tertarik untuk menanamkan modalnya di perusahaan tersebut. Hal ini sesuai dengan teori sinyal yang mengatakan bahwa rasio likuiditas yang tinggi dapat menunjukkan sinyal positif bagi investor dan kreditur karena perusahaan dianggap telah mampu untuk menutupi kewajiban lancarnya dan dianggap baik untuk pengelolaannya (Agustini \& Wirawati, 2019). Perusahaan yang memiliki likuiditas yang tinggi juga akan memiliki posisi kas yang baik juga sehingga perusahaan tersebut dapat dengan lancar melakukan pembayaran modal sesuai dengan yang sudah disepakati.

Hasil penelitian ini sesuai dengan hasil penelitian yang dilakukan oleh Lasut et al. (2018) yang menyatakan bahwa likuiditas berpengaruh signifikan terhadap struktur modal. Namun, hasil penelitian ini tidak sesuai dengan penelitian yang dilakukan oleh Novwedayaningayu \& Hirawati (2020) yang menyatakan bahwa likuiditas tidak berpengaruh terhadap struktur modal.

\section{Pengaruh Risiko Bisnis Terhadap Struktur Modal}

Hasil dari penelitian ini menunjukan bahwa risiko bisnis tidak berpengaruh terhadap struktur modal karna bahwa tinggi rendahnya risiko bisnis tidak mempengaruhi struktur modal karena perusahaan dengan risiko bisnis yang besar berada dalam ketidakpastian, ketidakpastian dalam untuk memilih menggunakan dana internal atau dana eksternal. Tetapi perusahaan yang memiliki risiko yang besar memerlukan dana yang cukup besar untuk menjalankan kegiatan operasionalnya, salah satu alternatifnya adalah menggunakan dana eksternal (hutang). Namun karena risiko bisnis yang besar maka pihak kreditur khawatir jika perusahaan tidak dapat memenuhi kewajibannya, sehingga kreditur memerlukan pertimbangan juga dalam memberikan pinjamannya.

Hasil penelitian ini sesuai dengan hasil penelitian yang dilakukan oleh Permatasari et al. (2019) yang menyatakan bahwa struktur aset berpengaruh signifikan terhadap struktur modal. Namun, hasil penelitian ini tidak sesuai dengan penelitian yang dilakukan oleh Velda 
et al. (2020) yang menyatakan bahwa struktur aset tidak berpengaruh terhadap struktur modal.

\section{KESIMPULAN}

Hasil penelitian menunjukkan bahwa likuiditas berpengaruh negatif terhadap struktur modal, sedangkan struktur asset, profitabilitas dan resiko bisnis tidak berpengaruh terhadap struktur modal. Dalam penelitian ini terdapat beberapa keterbatasan, yang pertama adalah banyak perusahaan industri barang konsumsi yang tidak melaporkan data secara lengkap mengenai. Yang kedua adalah variabilitas variabel dependen yang dapat dijelaskan oleh variabel independen hanya sebesar $50,2 \%$, sedangkan sisanya dipengaruhi oleh faktor lain sebanyak 49,8\%. Atas keterbatasan tersebut, peneliti selanjutnya disarankan untuk menggunakan juga prediktor selain dan juga menggunakan sampel selain perusahaan yang bergerak dalam sektor property dan real setate.

\section{DAFTAR PUSTAKA}

Agustini, N. W., \& Wirawati, N. G. P. (2019). Pengaruh Rasio Keuangan Pada Financial Distress Perusahaan Ritel Yang Terdaftar di Bursa Efek Indonesia (BEI). E-Journal Akuntansi, 26 (1), 251-280.

Andika, I. K. R., \& Sedana, I. B. P. (2019). Pengaruh Profitablitas, Struktur Aktiva dan Unkuran Perusahaan Terhadap Struktur Modal. EJurnal Manajemen, 8 (9), 58035824.

Aurelia, L., \& Setijaningsih, H. T. (2020). Analisis Pengaruh Struktur Aset, Pertumbuhan Aset dan Ukuran Perusahaan Terhadap Struktur Modal. Jurnal Multiparadigma Akuntansi Tarumanagar, 2, 801-807.

Bong, S. (2019). Manajemen Resiko, Krisis, \& Bencana untuk Industri Pariwisata yang Berkelanjutan. PT Gramedia Pustaka Utama.

Dewi, D. A. I. Y. M., \& Sudiartha, G. M. (2017). Pengaruh Profitabilitas, Ukuran Perusahaan, Dan Pertumbuhan Aset Terhadap Struktur Modal Dan Nilai Perusahaan. E-Jurnal Manajemen Unud, 6 (4), 2222-2252.

Fahmi, I. (2014). Analisis Kinerja Keuangan. CV Alpabeta.

Fahmi, I. (2017). Analisis Kinerja Keuangan. CV Alpabeta.

Gitman, L. (2012). . Principles of Managerial Finance. Boston Pearson Education.

Jati, A. K. N. (2016). The Influence of Managerial Ownership Structure, Asset Structure, Liquidity, Business Risk, Dividend Policy, Firm Size, and Profitability on The Capital Structure in The Firms of Hotel, Restaurant, and Tourism Industry. Journal of Research in Economics and Management, 16 (2), 355-366.

Kasmir. (2016). Manajemen Sumber Daya Manusia (Teori dan Praktik). PT Rajagrafindo 
Persada.

Khairuddin, F., Mahsuni, A. W., \& Afifudin. (2019). Pengaruh Good Corporate Governance dan Rasio Likuiditas terhadap Financial Distress di Perusahaan Manufaktur yang Terdaftar di BEI 2015-2018. Jurnal IImiah Riset Akuntansi, 8 (1), 142-158.

Khairudin, \& Wandita. (2017). Analisis Pengaruh Rasio Profitabilitas, Debt To Equity Ratio (DER) dan Price To Book Value (PBV) Terhadap Harga Saham Perusahaan Pertambangan Di Indonesia. Jurnan Akuntansi Keuangan, 8 (1), 68 - 84.

Komariah, N., \& Nurulrahmatiah, N. (2020). Pengaruh Struktur Aktiva Dan Likuiditas Terhadap Struktur Modal. BALANCE: JURNAL AKUNTANSI DAN BISNIS, 5 (2), 112 122.

Lasut, S. J. ., Rate, P. Van, \& Raintung, M. C. (2018). Pengaruh Ukuran Perusahaa, Profitabilitas, Dan Likuiditas Terhadap Struktur Modal Pada Perusahaan Otomotif Yang Terdaftar Di Bursa Efek Indonesia Periode 2012-2015. Jurnal EMBA: Jurnal Riset Ekonomi, Manajemen, Bisnis Dan Akuntansi, 6 (1), 11-20. https://doi.org/https://doi.org/10.35794/emba.6.1.2018.18705

Liang, I., \& Natsir, K. (2019). Pengaruh Profitabilitas, Likuiditas Dan Ukuran Perusahaan Terhadap Struktur Modal. Jurnal Manajerial Dan Kewirausahaa, 1 (3), 481-488.

Listyawati, Oemar, A., \& Supriyanto, A. (2017). Pengaruh Ukuran Perusahaan (Size), Profitabilitas (ROA), Growth dan Likuiditas Terhadap Struktur Modal Perusahaan Perbankan Syariah Periode Tahun 2011-2014. Jurnal Ilmiah Mahasiswa Akuntasi Unpand, 3 (3).

Maswani, Negoro, D. A., \& Syah, T. Y. R. (2021). The Analysis of Factors Related to the Company Performance with Capital Structure as an Intervening Variable in the Transportation Industry in Indonesia. Budapest International Research and Critics Institute-Journal, 4 (3), 4736-4752.

Melisa, R., \& Yuliandi. (2020). Pengaruh Profitabilitas, Risiko Bisnis, Kepemilikan Manajerial, Dan Pajak Terhadap Struktur Modal. Jurnal IImiah Akuntansi Kesatuan, 8 (1), 2736.

Muflihah, I. Z. (2017). Analisis Financial Distress Perusahaan Manufaktur Di Indonesia Dengan Regresi Logistik. Majalah Ekonomi, 22 (2), 254-269.

Novwedayaningayu, H. C., \& Hirawati, H. (2020). Pengaruh Profitabilitas, Likuiditas Dan Struktur Aktiva Terhadap Struktur Modal Pada Perusahaan Consumer Goods. Jurnal Sains Manajemen Dan Bisnis Indonesia, 10 (2), 255-262.

Permatasari, M., Sulistyo, \& Mustikowati, R. I. (2019). Pengaruh Ukuran Perusahaan, Profitabilitas, Struktur Aset, Pertumbuhan Penjualan Dan Likuiditas Terhadap Struktur Modal. Jurnal Riset Mahasiswa Akuntansi, (1).

Puspida, S., \& Budiyanto. (2013). Pengaruh Risiko Bisnis dan Pertumbuhan Aktiva terhadap Struktur Modal pada PT Pembangkitan Jawa Bali. Jurnal IImu Dan Riset Manajemen, $2(2), 1-15$.

Riasita, D. (2014). Pengaruh Profitabilitas, Likuiditas, Pertumbuhan Aktiva, Struktur Aktiva dan Ukuran Perusahaan terhadap Struktur Modal. Universitas Negeri Yogyakarta.

Sari, N. P. A. S. P., \& Suryantini, N. P. S. (2019). Pengaruh Profitabilitas, Likuiditas, Dan 
Tingkat Pertumbuhan Terhadap Kebijakan Dividen Pada Perusahaan Manufaktur. EJurnal Manajemen, 8 (7), 4559-4588.

Sartono, A. (2016). Manajemen Keuangan Teori dan Aplikasi. BPFE-Yogyakarta.

Septiani, N. P. N., \& Suaryana, I. G. N. A. (2018). Pengaruh Profitabilitas, Ukuran Perusahaan, Struktur Aset, Risiko Bisnis dan Likuiditas pada Struktur Modal. EJournal Akuntansi, 22 (3), 1682-1710.

Sudana, I. M. (2015). Manajemen Keuangan Perusahaan. Erlangga.

Suherman, Purnamasari, R., \& Mardiyati, U. (2019). Pengaruh Struktur Aset, Likuiditas, dan Profitabilitas terhadap Struktur Modal yang Dimoderasi Oleh Ukuran Perusahaan. Jurnal IImiah Manajemen, 2.

Sutra, F. M., \& Mais, R. G. (2019). Faktor-Faktor yang Mempengaruhi Financial Distress dengan Pendekatan Altman Z-Score pada Perusahaan Pertambangan yang Terdaftar di Bursa Efek Indonesia Tahun 2015-2017. Jurnal Akuntansi Dan Manajemen, 16 (1), 34-72.

Trisna, I. K. E. R., \& Gayatri, G. (2019). Ukuran Perusahaan Memoderasi Pengaruh Free Cash Flow dan Leverage Terhadap Kebijakan Dividen. E-Journal Akuntansi, 26 (1), 484-509. https://doi.org/https://doi.org/10.24843/EJA.2019.v26.i01.p18

Velda, L., Sinaga, A. N., Susanti, E., Yaputra, C., \& Veronica. (2020). Analisis Profitabilitas, Ukuran Perusahaan, Struktur Aset, Likuiditas, Dan Risiko Bisnis Terhadap Struktur Modal Perusahaan Manufaktur Di Indonesia. Journal of Economic, Business and Accounting, 3 (2).

Weston, J. F., \& Copeland, T. E. (2010). Manajemen Keuangan Jilid 2. Binarupa Aksara Publisher.

Wiagustini, N. L. P., \& Pertamawati, N. P. (2015). Pengaruh Risiko Bisnis Dan Ukuran Perusahaan Terhadap Struktur Modal Dan Nilai Perusahaan Pada Perusahaan Farmasi Di Bursa Efek Indonesia. Jurnal Manajemen, Strategi Bisnis Dan Kewirausahaa, 9 (2), 112-122.

Widayanti, L. P., Triaryati, N., \& Abundanti, N. (2016). Pengaruh Profitabilitas, Tingkat Pertumbuhan Perusahaan, Likuiditas, Dan Pajak Terhadap Struktur Modal Pada Sektor Pariwisata. E-Jurnal Manajemen Unud, 5 (6), 3761-3793. 